\title{
SOME EFFECTS OF STEROIDS ON THE IMMATURE MOUSE OVARY IN VITRO
}

\author{
JOYGE KENT \\ United Birmingham Hospitals Department of Clinical Endocrinology, \\ Birmingham and Midland Hospital for Women, Birmingham B11 $4 H L$
}

(Received 11th Fuly 1972)

\begin{abstract}
Summary. Ovaries of 15-day-old mice were cultured in vitro with steroids of the oestrogen biosynthetic pathways. Most steroids stimulated $\left[{ }^{3} \mathrm{H}\right]$ thymidine uptake at 1 or $0.1 \mu \mathrm{g} / \mathrm{ml}$ but $100 \mu \mathrm{g} / \mathrm{ml}$ of pregnenolone and $10 \mu \mathrm{g} / \mathrm{ml}$ of testosterone were required. Pregnenolone, testosterone and oestradiol-17 $\beta$ stimulated growth of small follicles but inhibited mitosis in those with three or more layers. The physiological significance of these high steroid levels is briefly discussed and the induced patterns of follicle growth are contrasted with those due to FSH or LH.
\end{abstract}

\section{INTRODUCTION}

In ovaries from 15-day-old mice cultured in vitro with $\mathrm{LH}$, no follicle growth occurred for 3 days (Ryle, 1971a). Between Day 3 and Day 6 of culture, however, the number of follicles with three or more layers of granulosa cells increased markedly and the largest follicles grew very rapidly. Luteinizing hormone is necessary for the normal development of the mouse ovarian theca (Eshkol, Lunenfeld \& Peters, 1970) and daily injections of HCG from birth initiate its premature development (Brandau, 1970). Küppers (1967) observed increased activity of various enzymes, including steroid $3 \beta$-ol dehydrogenase, in the thecal cells of prepubertal rats after a series of HCG injections suggesting that steroidogenesis might be initiated. On the other hand, Lostroh (1959) and Fainstat (1968) noted that mitosis was stimulated in granulosa cells of mouse and rat ovaries cultured with oestrogen. It seemed possible, therefore, that LH promoted steroid enzyme production in the theca interna of the cultured ovaries and that sufficient oestrogen was produced in the tissue to increase granulosa cell mitosis.

The experiments described below were designed to test whether any of a number of steroids of the two major pathways of oestrogen biosynthesis affected follicle growth in the ovaries of 15-day-old mice cultured in vitro. Thymidine uptake provides a satisfactory indicator of enhanced follicular development due to FSH (Ryle, 1969a, b), and was used as an indicator of similar responses to steroids in the present work. Parallel morphological studies, using five steroids, were carried out to determine the stage of maturation at which the follicles responded. 


\section{MATERIALS AND METHODS}

The breeding and rearing of the mice were as described previously (Ryle, 1969a). During the course of the work, the culture procedure I, described by Ryle (1971b), was modified by a change in the medium and buffering system used (culture procedure II; Boggis \& Ryle, 1972). Steroid hormones (British Drug Houses Ltd, Poole, Dorset; Koch-Light \& Co. Ltd, Colnbrook, Bucks) were dissolved in absolute ethanol and serial dilutions were prepared in culture medium for dispensing to the dishes. Each steroid was tested at 100,10,1 and $0.1 \mu \mathrm{g} / \mathrm{ml}$. Four or five replicate pairs of dishes were set up for each test, one of each pair containing steroid and the other, a corresponding concentration of alcohol (2 to $0.002 \%$ ). Pairs of ovaries from 15-day-old mice were allocated at random to the pairs of dishes. Mouse body weights ranged from 5.0 to $8.0 \mathrm{~g}$ but the variation within an experiment did not exceed $1.5 \mathrm{~g}$. The ovaries were cultured for 3 or 4 days, i.e. a period shorter than that used to detect LH stimulation of follicle growth.

In the thymidine uptake experiments, $0.2 \mu \mathrm{Ci}\left[\mathrm{Me}_{-}{ }^{3} \mathrm{H}\right]$ thymidine $(18.3$ $\mathrm{Ci} / \mathrm{mmol}$; The Radiochemical Centre, Amersham) in $0.1 \mathrm{ml}$ medium was added to each dish after 1 day of culture. At the end of the culture period, the ovaries were prepared for counting and the uptake of label was estimated (cf. Ryle, $1971 \mathrm{~b}$ ), or they were prepared for morphological investigation as described by Ryle (1971a). In a few experiments, to facilitate the identification of actively growing follicles, Colcemid (final concentration, $0.5 \mu \mathrm{g} / \mathrm{ml}$; CIBA Laboratories, Horsham, Sussex) was added to the dishes $7 \mathrm{hr}$ before the ovaries were fixed. Serial sections were prepared and the number of follicles with three and with four or more layers of granulosa cells was determined for each ovary (cf. Ryle, 1969a). Where Colcemid was used, counts were made of mitotic figures in the granulosa cells of the measured follicle sections. The significance of quantitative differences between experimental and control ovaries was estimated by means of the modification of Student's $t$ test appropriate to paired data. The $\chi^{2}$ test for $2 \times 2$ contingency tables was used to compare ratios.

\section{RESULTS}

\section{Uptake of $\left[{ }^{3} \mathrm{H}\right]$ thymidine}

Table I presents the data on culture procedure and duration as well as the results of each experiment that showed a significant steroid effect on thymidine uptake. Pregnenolone $(100 \mu \mathrm{g} / \mathrm{ml})$ stimulated uptake whereas this concentration of almost all other steroids tested depressed it. The depression due to progesterone, androstenedione, dehydroepiandrosterone and oestradiol-17 $\beta$ was especially marked.

Progesterone, oestradiol-17 $\beta$ and oestrone were also inhibitory at a concentration of $10 \mu \mathrm{g} / \mathrm{ml}$, but testosterone at this concentration markedly stimulated thymidine uptake. The remainder had no significant effect. With the exception of pregnenolone and testosterone, all the steroids stimulated thymidine uptake at a concentration of either 1 or $0.1 \mu \mathrm{g} / \mathrm{ml}$.

The differing response to various concentrations was not related to the small 


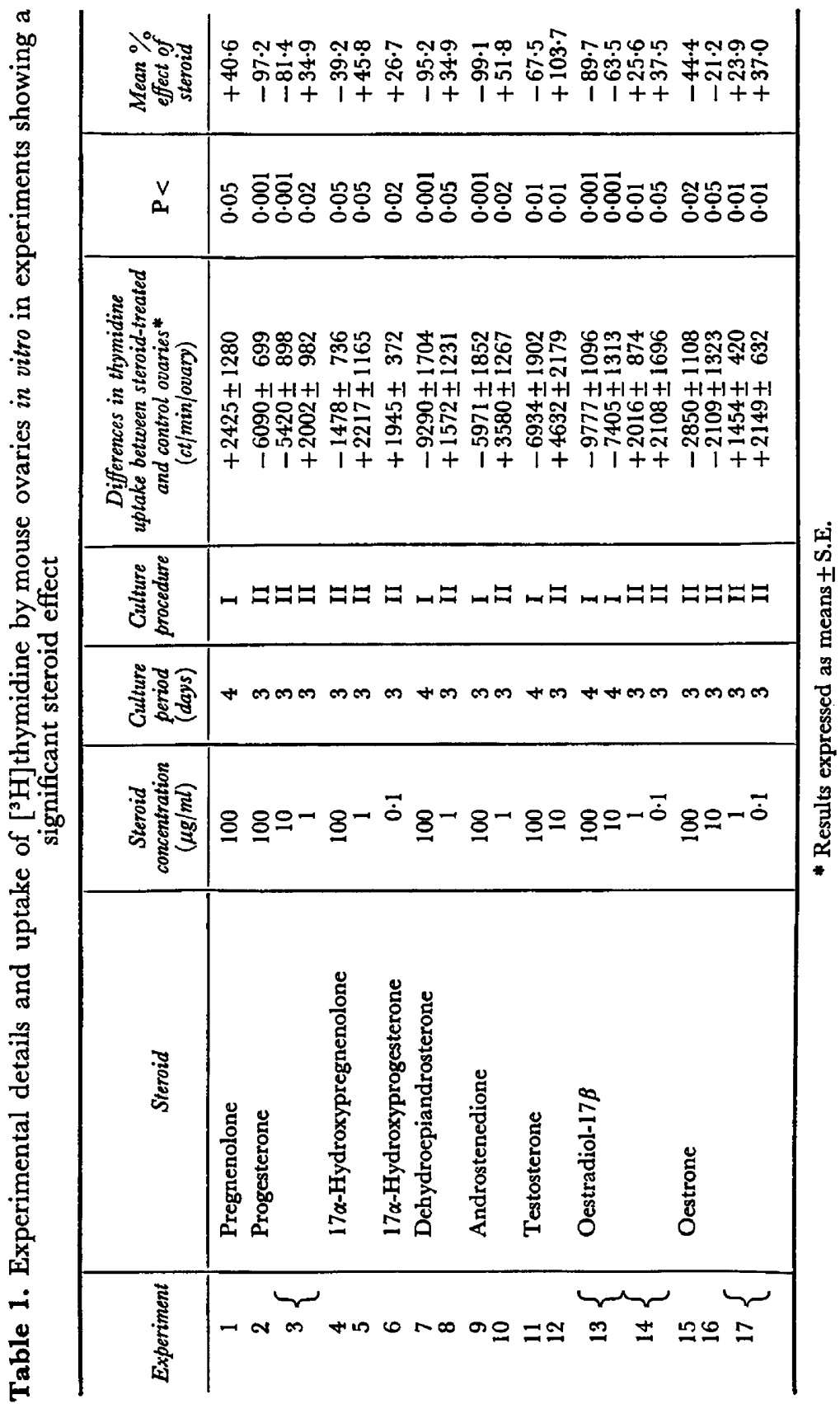


but varying alcohol content of the medium, nor was it due to the use of different culture procedures or different culture periods. Thus, replicate experiments with 100 and $10 \mu \mathrm{g}$ progesterone $/ \mathrm{ml}, 10 \mu \mathrm{g}$ dehydroepiandrosterone $/ \mathrm{ml}$ and $10 \mu \mathrm{g}$ testosterone/ml, using the alternative culture procedure, gave essentially the same results. Similarly $10 \mu \mathrm{g}$ dehydroepiandrosterone $/ \mathrm{ml}$ and $10 \mu \mathrm{g}$ testosterone $/ \mathrm{ml}$ produced similar responses during either 3 or 4 days of culture.

\section{Morphology}

Table 2 shows the effects of pregnenolone, progesterone, androstenedione, testosterone and oestradiol-17 $\beta$ on the mean number per ovary of follicles with three or more layers of granulosa cells and on the mean number of mitotic figures in these follicles. Pregnenolone increased the numbers of follicles recorded because it increased those which had three layers (mean differences \pm S.E.: $+18 \cdot 8 \pm 6 \cdot 7, P<0 \cdot 001$, Exp. A; $+3 \cdot 2 \pm 2 \cdot 9, P<0 \cdot 1$, Exp. B). In Exp. B, it significantly decreased the mean number of mitotic figures per follicle. Pregnenolone did not significantly affect the number of larger follicles in either experiment, probably because it tended to depress mitosis.

The number of follicles was not significantly reduced by $1 \mu \mathrm{g}$ progesterone $/ \mathrm{ml}$ but the mean number of mitotic figures per follicle was less. By contrast, 0.5 $\mu \mathrm{g} / \mathrm{ml}$ tended to increase mitosis. The proportion of follicles containing more than ten mitotic figures was significantly increased $(P<0.01)$. Androstenedione, $1 \mu \mathrm{g} / \mathrm{ml}$, had no effect either on the number of follicles or on the frequency of mitosis in their granulosa cells.

Although the total number of recorded follicles was not significantly changed by $10 \mu \mathrm{g}$ testosterone/ml in Exps $\mathrm{G}$ and $\mathrm{H}$, the number with three layers only was significantly increased in both Exps $F$ and $H$ (mean differences \pm S.E.: $+8 \cdot 0 \pm 4 \cdot 8, P<0.05$, Exp. F; $+3 \cdot 0 \pm 3 \cdot 4, P<0 \cdot 1$, Exp. H). The number of mitotic figures/follicle was significantly decreased in Exp. $\mathrm{H}$ and the number of follicles lacking mitotic figures was increased (mean difference \pm S.E.: $+2 \cdot 0 \pm 0 \cdot 6, P<0 \cdot 001)$.

The effects of 100 and of $10 \mu \mathrm{g}$ oestradiol- $17 \beta$ on the number of recorded follicles were variable. Thus $100 \mu \mathrm{g} / \mathrm{ml}$ had no effect in Exp. I but significantly reduced follicle number in Exp. J. Moreover, $10 \mu \mathrm{g} / \mathrm{ml}$ significantly increased the follicle numbers in Exp. I but tended to reduce it in Exp. J. There were no follicles with more than three layers in Exp. $J$ and none with more than four layers in Exp. I. Mitotic frequency was significantly reduced by $100 \mu \mathrm{g}$ oestradiol-17 $\beta / \mathrm{ml}$ (Exp. J). Lower concentrations increased the numbers of recorded follicles, the effect of $1 \mu \mathrm{g} / \mathrm{ml}$ being significant both in Exp. $\mathrm{K}$ and in Exp. $\mathrm{L}$. Simultaneously, mitotic frequencies were reduced by $1 \mu \mathrm{g} / \mathrm{ml}$ (Exp. L).

\section{DISCUSSION}

The results of the thymidine uptake experiments suggested that each of the steroids tested, when used at an appropriate concentration, was able to stimulate mitosis in cultured mouse ovaries. The concentrations which significantly affected $\left[{ }^{3} \mathrm{H}\right]$ thymidine uptake and ovarian morphology were, however, considerably higher than the physiological ranges present in plasma. Exley 


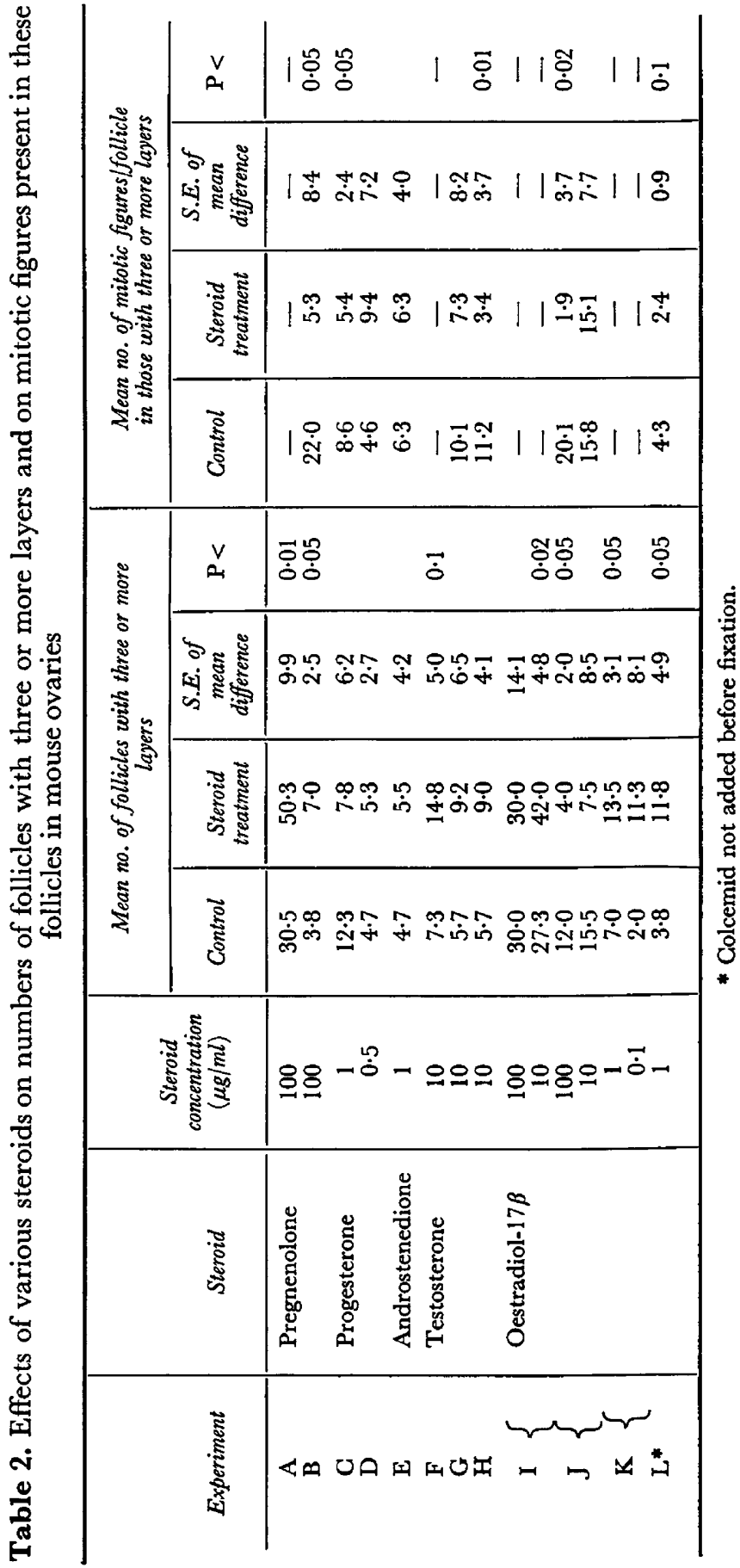


(1969) reported 0.01 to $0.02 \mathrm{ng} / \mathrm{ml}$ oestradiol-17 $\beta$ and Armstrong, Miller \& Knudsen (1969), $22 \mathrm{ng}$ progesterone/ml in the peripheral circulation of the non-oestrous rat. A mouse ovary weighing approximately $1 \mathrm{mg}$ contained at equilibrium $0.004 \mu \mathrm{g}$ oestradiol-17 $\beta$ when cultured with $0.7 \mu \mathrm{g}$ of the tracelabelled steroid per ml (J. Kent, unpublished observation). Though the tissue concentration of steroid in these experiments was high, it is possible that high local concentrations occur close to the site of production in vivo, and are physiologically important. Thus, Short, McDonald \& Rowson (1963) found $1 \mu \mathrm{g}$ progesterone $/ \mathrm{ml}$ in the ovarian vein of the sheep compared to $0.005 \mu \mathrm{g} / \mathrm{ml}$ $(5 \mathrm{ng} / \mathrm{ml})$ in peripheral plasma.

Inhibition of thymidine uptake by high steroid concentrations might have been related to the respiratory inhibition observed at similar concentrations in certain fractions of many tissues (Tomkins \& Maxwell, 1963). Alternatively, inhibition of particular steroidogenic enzymes may have been involved (cf. Neher \& Kahnt, 1965; Villee, 1966; Haksar, Romanoff, Hagino \& Pincus, 1967). Lower concentrations of oestradiol-17 $\beta$ have been shown to stimulate follicle growth in cultured ovaries $(2 \mu \mathrm{g} / \mathrm{ml}$, Lostroh, $1959 ; 0.1 \mu \mathrm{g} / \mathrm{ml}$, Fainstat, 1968 ) and in hypophysectomized animals (Pencharz, 1940; review by Meyer \& Bradbury, 1960), but the means by which mitosis is stimulated is unknown. The switch, within a tenfold concentration difference, between inhibition and stimulation suggests the possibility of a control system geared to fluctuations in the rate of steroid hormone synthesis. The exceptionally high concentration of pregnenolone required for stimulation may have been due to slow diffusion into the tissue; equilibrium is reached only after $24 \mathrm{hr}$ compared to $8 \mathrm{hr}$ for oestradiol-17 $\beta$ (J. Kent, unpublished observation). More probably, however, pregnenolone serves as a precursor for the production of an active steroid. Some of the other steroids tested may also be converted to an active form within the tissue.

Growth of follicles with fewer than three layers of granulosa cells evidently occurred in response to pregnenolone, testosterone and oestradiol-17 $\beta$ since the number with three or more layers increased. Yet, mitosis was inhibited in these larger follicles. This is in marked contrast to the effects of oestrogen on follicle growth in hypophysectomized rats, where numerous quite large follicles develop (Croes-Buth, Paesi \& de Jongh, 1959). Possibly, this dissimilarity arises from differences in the maturity of the follicle population when tested.

The pattern of follicle growth initiated in vitro in 15-day-old mouse ovaries by these steroid hormones differed from that due either to FSH or to LH. Granulosa cell mitosis was rapidly promoted by FSH in follicles of all sizes (Ryle, 1972) whereas LH preferentially stimulates growth in follicles with three or more layers, but only after 3 days culture (Ryle, 1971a, 1972). Moreover, high concentrations of LH appear initially to inhibit mitosis in follicles with fewer than three layers of granulosa cells (J. A. Boggis and M. Ryle, unpublished observations). It is therefore unlikely that LH stimulates follicle growth by increasing the concentration of steroid in the tissue or that the delayed response to LH merely reflects the time required to accumulate sufficient oestrogen in the medium. It remains to be seen whether the spectra of follicle sizes responsive to these different hormones are identical in vivo. 


\section{ACKNOWLEDGMENTS}

I wish to thank Dr W. R. Butt and Dr M. Ryle for their advice and encouragement and Miss E. Payne and Miss L. Wilkins for technical assistance. The work was supported by a grant from the Ford Foundation.

\section{REFERENCES}

Armstrong, D. T., Miller, L. S. \& Knudsen, K. A. (1969) Regulation of lipid metabolism and progesterone production in rat corpora lutea and ovarian interstitial elements by prolactin and $\mathrm{LH}$. Endocrinology, 85, 393.

Boggis, J. A. \& Ryle, M. (1972) An in vitro procedure for the quantitative measurement of follicle stimulating hormone activity. 7 . Endocr. 54, 355.

BrANDAU, H. (1970) Histochemical localization of enzyme activities in normal and gonadotrophin stimulated mouse ovaries. In: Gonadotrophins and Ovarian Development, p. 307. Eds. W. R. Butt, A. G. Grooke and M. Ryle. Livingstone, Edinburgh and London.

Croes-Buth, S., Paesi, F. J. A. \& De Jongh, S. E. (1959) Stimulation of ovarian follicles in hypophysectomised rats by low dosages of oestradiol benzoate. Acta endocr., Copenh. 32, 399.

Eshrol, A., Lunenfeld, B. \& Peters, H. (1970) Ovarian development in infant mice. Dependence on gonadotrophic hormones. In: Gonadotrophins and Ovarian Development, p. 249. Eds. W. R. Butt, A. C. Grooke and M. Ryle. Livingstone, Edinburgh and London.

ExLEy, D. (1969) The ultramicrodetermination of oestrogens in rat peripheral plasma. Acta endocr., Copenh. 61, Suppl. 138, 18.

Fainstat, T. (1968) Organ culture of postnatal rat ovaries in chemically defined medium. Fert. Steril. 19, 317.

Haksar, A., Romanoff, E., Hagino, N. \& Pincus, G. (1967) In vitro inhibition of cholesterol synthesis by pregnenolone in bovine corpus luteum. Steroids, $9,405$.

Küppers, S. (1967) Zur Fermenthistochemie des Rattenovariums während der postnatalen Entwicklung. Acta histochem. 27, 267.

LostroH, A. J. (1959) The response of ovarian explants from post-natal mice to gonadotrophins. Endocrinology, 65, 124.

Meyer, J. E. \& Bradbury, J. T. (1960) Influence of stilbestrol on the immature rat ovary and its response to gonadotrophin. Endocrinology, 66, 121.

Neher, R. \& KahNT, F. W. (1965) On the biosynthesis of testicular steroids in vitro and its inhibition. Experientia, 21, 310.

Pencharz, R. I. (1940) Effect of estrogens and androgens alone and in combination with chorionic gonadotrophin on the ovary of the hypophysectomised rat. Science, N.r. 91, 554.

Ryle, M. (1969a) A quantitative in vitro response to follicle-stimulating hormone. 7 . Reprod. Fert. 19, 87.

RyLE, M. (1969b) Morphological responses to pituitary gonadotrophins by mouse ovaries in vitro. $\mathcal{F}$. Reprod. Fert. 20, 307.

RYLE, M. (1971a) The time factor in responses to pituitary gonadotrophins by mouse ovaries in vitro. 7. Reprod. Fert. 25, 61 .

RYLE, M. (1971b) The activity of human follicle-stimulating hormone preparations as measured by a response in vitro. 7 . Endocr. 51, 97.

Ryle, M. (1972) The growth in vitro of mouse ovarian follicles of different sizes in response to purified gonadotrophins. 7. Reprod. Fert. 30, 395.

Short, R. V., McDonald, M. F. \& Rowson, L. E. A. (1963) Steroids in the ovarian venous blood of ewes before and after gonadotrophic stimulation. 7. Endocr. 26, 155.

Tomkins, G. M. \& Maxwell, E. S. (1963) Some aspects of steroid hormone action. A. Rev. Biochem. 32, 677.

Viltee, D. B. (1966) Effects of progesterone on enzyme activity of adrenals in organ culture. Adv. Enzyme Reguln, 4, 269. 